\section{Tenure under Fire}

A STRANGE alliance of bedfellows has begun to mount an attack on one of the accepted and most jealously guarded facets of academic life - the institution of tenure. For long the acclaimed defender of academic freedom and of the right of university faculty members to pursue their teaching and research without fear of political interference, tenure is being criticized by radical students, conservatives and legislators of all kinds, although from widely differing standpoints. The upshot is that although it would be an exaggeration to describe the sum total of the criticisms as a frontal assault on the institution, those who support the concept of tenure are increasingly on the defensive.

Several factors have combined to cause discontent with the traditional concept of tenure-campus disturbances, financial stringencies in nearly all sectors of higher education and the continuing reappraisal of the whole role of higher education. Another increasingly evident factor is the growing unionization of university teaching staff and the consequent proliferation of collective bargaining in many institutions of higher education.

Many large universities and educational organizations have recently decided to take a close look at the way tenure is working and to see whether indeed it is as much a detriment as an asset to higher education. Last year, the President's Commission on Campus Unrest and the American Council on Education both concluded, although in a peculiarly indefinite way, that tenure is in part responsible for causing campus disturbances-chiefly through the influence on students of radical staff members who hold tenured positions and, among the universities that are conducting their own studies, Harvard has been the first off the mark with the publication earlier this month of a discussion memorandum which is, in many respects, a rousing defence of the concept and the workings of academic tenure (Discussion Memorandum on Academic Tenure, prepared by the University Committee on Governance).

The concept of tenure, which is essentially the right of an appointed faculty member to retain that position until he retires, is usually defended chiefly because it protects university staff from political harassment. Consequently, attacks on the system have tended in the past to come from conservative legislators who are entirely impotent to remove from office radical professors whose teaching may run counter to the accepted political order. A striking demonstration of the protection afforded by tenure is the case of $\mathrm{Dr}$ Clark Kerr, who was dismissed from the presidency of the University of Southern California, but immediately resumed his tenured position as professor of economics in the university. The board of regents, although able to dismiss him from the presidency, was powerless to remove him from his tenured position in the university.

Although the strident voices of those who accuse radical professors of hiding under the protective shield of tenure to ferment discontent on the campuses can still be heard, they have recently been forced to share their platform with the more radical critics of present university practices, who charge that the tenure system simply allows dead wood to remain in the universities by tying up tenured positions and allowing only limited scope for the infusion of new blood in the upper echelons of academe. A common rider to this criticism is that tenure has become an outdated instrument for protecting academic freedom since long-term contracts and the growing power of the unions on the campuses can be just as powerful a force against political interference in academic business.

Yet another criticism comes chiefly from educational administrators and legislators who argue that in times of severe financial stringency, inflexibility is imposed on the new staff appointments and on rearranging departments and faculties because tenured staff will soak up much of the available funds for salaries. There is also the argument that departments which have been built up to what later appears to be excessive proportions cannot easily be run down when they are filled with a multitude of staff in tenured positions. Such a situation, of course, offends the legislator's sense of business efficiency.

The Harvard memorandum deals with both these points by invoking the argument that turnover of staff is a sufficient guarantee that new blood will continually be called in to replace those older members of staff who leave the university, and, as for the suggestion that money could be saved by playing the market when hiring staff during times of financial stringency, the Committee on Governance tartly suggests "if the university were to take advantage of the present buyer's market and to do so without regard to quality, a considerable reduction in salary might well be gained". In short, the committee suggests that the guarantee of tenure at
Harvard is often more important than mere salary and that without tenure it would probably require a larger salary carrot to entice quality staff members to the university.

Another commonly heard criticism of tenure is that it encourages faculty members to undertake more work outside the university, thereby decreasing institutional loyalties. The argument goes along the lines that since a faculty member is safe in the knowledge that his tenured position is in little danger of being taken away, he needs to devote less time to his university, and he can pile up more consultancy work for himself outside. The President's Commission on Campus Unrest was particularly insistent that faculty should be made to limit their outside commitments since a decrease in institutional loyalty is a major factor in spreading disillusionment with the established order in higher education. The Harvard committee gives short shrift to the notion that tenure is in some way responsible, however, suggesting on the contrary that it serves to insulate faculty members from economic pressures and that without the security of tenure faculty members may even be driven to seek outside sources of income.

But in the final analysis academic freedom is the chief factor in the argument about tenure. That is why many university members have been watching with interest the developments on the campus of Stanford University during the past few months. A radical faculty member at Stanford was suspended from teaching and brought before a committee of eminent professors charged with the task of advising whether he should be dismissed. The faculty member, Dr H. Bruce Franklin, was suspended chiefly because of his participation in a demonstration which led to the shouting down of Mr Henry Cabot Lodge, the former US ambassador to South Vietnam, when he gave a lecture at Stanford in January, and also because he is alleged to have incited students to occupy the university computer centre a month later-a demonstration which led to several arrests and injuries. Dr Franklin was suspended in February by Mr Richard Lyman, the university president, who asserted that his activities constituted a threat to the workings of the university. The committee report was sent to Mr Lyman a week before Christmas but no final decision on whether Dr Franklin would be dismissed had been taken when Nature went to press. 